(C) 1992 ISIJ IIIIIIIIIIIIIII! 論 文

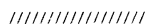

\section{溶融スラグ浴上における石炭の 急速熱分解生成物}

\title{
Pyrolyzed Products of Coal Rapidly Heated on a Molten Slag
}

\author{
Takafumi KaWAMURA and Hidetake ISHIKAWA
}

\begin{abstract}
Synopsis :
Behavior of rapid pyrolysis of coal is of considerable importance in understanding an early stage of post combustion in an iron ore smelting reduction converter.

Products by pyrolysis of various kinds of coal under conditions of high heating rate and high temperature on a molten slag have been studied quantitatively.

By analyzing the pyrolysis products such as gas, tar and residual char, data were obtained as a function of coal rank (eleven coals and one metallurgical coke), temperature $\left(1350 \sim 1500^{\circ} \mathrm{C}\right)$, gas residence time $(2.5$ $\sim 10 \mathrm{~s})$, and coal diameter $(0.8 \sim 7.0 \mathrm{~mm})$ in the experiments using high frequency induction furnace.

Total coal volatiles released in these experiments increased by 10 to $20 \%$ compared to the proximate volatile matters. Carbon oxide gas $\left(\mathrm{CO}+\mathrm{CO}_{2}\right)$ and hydrocarbon gas $\left(\mathrm{CH}_{4}-\mathrm{C}_{3} \mathrm{H}_{6}\right)$ yields increased with increasing $[\mathrm{O}]$ content and $[\mathrm{H}] /[\mathrm{C}]$ atomic ratio in parent coal, respectively.

The effect of coal diameter and slag temperature on total volatiles did not become significant.

The ratio of $[\mathrm{S}]$ and $[\mathrm{N}]$ retained in residual char to total $[\mathrm{S}]$ and $[\mathrm{N}]$ contained in parent coal decreased with increasing volatile matter of coal. Normalization of the data, by taking the ratio of $[S]$ and $[N]$ released to total volatiles released, indicated that $[S]$ and $[N]$ in all coals examined were preferentially retained in volatiles and showed the maximum retention at around $[\mathrm{C}]_{d a f}=85 \%$ coal.
\end{abstract}

Key words : coal ; rapid pyrolysis; products; molten slag; smelting reduction.

\section{1. 緒}

\section{言}

鉄浴式浴融還元炋に抏いて，不岑を熱源および還元材 として直接投入した場合，酸素ジェットによる燃焼の前 段階としての熱分解挙動を十分に把握することが，灯内 三次燃焼求よび着熱現象を理解する上で重要である。

例えば，松尾ら”は固定炭素バランスの考え方から， 不炭の熱分解によって生成するチャー量が二次燃焼率に 及ぼす影響を明らかにし，揮発分の少ない石炭ほど二次 燃焼率が高くなるとしている，浴融還元义伈条作に招け るチャーの生成量は，白金るつぼを用いて， $900^{\circ} \mathrm{C}, 7$ $\min \sigma \mathrm{N}_{2}$ 気流中で測定する JIS I業分析值とは異な り，高温度場，急速加熱条件でのデー夕が必要となる。

石炭の急速加熱下に扔ける熱分解挙動は，ガス化や燃 焼に関連して注目を浴び，急速熱分解のすぐれた解説も

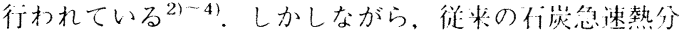
解の研究は，ほとんどのものが $1000^{\circ} \mathrm{C}$ 前後の低温下 に扔ける研究で，鉄浴灯の温度レベルである $1500^{\circ} \mathrm{C}$ 近傍という高温下での研究は，非帘に少ない5)-91.また， 高温での研究は主に微粉炭燃焼を対象として行われてい るため，数十ミクロンの微粉を取り扱って拀り，溶融還 元のような粗粘を対象とした研究はほとんど見られな い.

そこで，本報では浴融スラグ浴を朋いた活温度場，急 速加熱条件下での矢験により，種々の不荻の熱分解生成 物を分量的に把握することで，鉄浴式浴融還元プロセス 開発のための一助とすることに狙いがある。また，溶銑

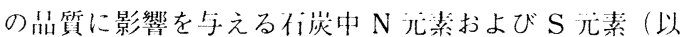
下， [N] 抢よび $[\mathrm{S}]$ のように表乱する）の熱分解生成 物への分配についても検討した。

平成元年 4 月本会講演大会にて発表 平成 3 年 6 月 12 日受付 (Received June 12, 1991)

* 新日本製鉄(株)プロセス技術研究所 (Process Technology Research Laboratories, Nippon Steel Corp., 20-1 Shintomi Futtsu 299-12)

*2 新H本製鉄(株)製鋼研究七ンター（現：(財)神奈川科学技術アカデミー） I博（Steelmaking Technology Lab., Nippon Steel Corp., Now Kanagawa Academy of Science and Technology) 


\section{2. 実験方法および装置}

奏験装埕の概琶を Fig. 1 に示す。 $15 \mathrm{~kg}$ の高㓤波誘 導炉内に㯰かれたカーボンるつぼに鉄を約 $800 \mathrm{~g}$ ，スラ グを約 $100 \mathrm{~g}$ (組成 $\mathrm{CaO}: \mathrm{SiO}_{2}: \mathrm{Al}_{2} \mathrm{O}_{3}: \mathrm{MgO}=45: 35$ $: 10: 10 \mathrm{wt} \%)$ を装入し, 所定の温度に制御し溶融させ る。一起流量の Ar を灼内に流しながら，溶融スラグ浴 にに $10 \mathrm{~g}$ の精科した石荻を，水冷ノズルを通して落下 させる，保菼のホッパー内は，あらかじめ Ar 雲囲気に しておく，不炭の荠下と间時にガス流路を切り替え, 乾 式ガスメータ一でガス流量を测定しつつ，ガスサンプリ ングバックに熱分解牛成ガスを捕集する。

捕集したガスは、ガスクロマトグラフで $\mathrm{H}_{2}, \mathrm{CO}, \mathrm{CO}_{2}$. $\mathrm{CH}_{4}, \mathrm{C}_{2} \mathrm{H}_{4}, \mathrm{C}_{2} \mathrm{H}_{6}, \mathrm{C}_{3} \mathrm{H}_{6}, \mathrm{C}_{3} \mathrm{H}_{8}$ の各ガス成分を絶対 検量線法で 2 回分析し，その平均值を採用した。 ガス分 析䛊差は土5\%であった。タールおよびすすの一部は, グラスウール允填のフィルターで捕集した後, 重量測定 を行った。るつぼ内の残留チャーは, Ar 雲网気下で室 温まで邻却後，スラグ上に浮いている全量のチャーを回
収し，重量測定および工業分析・元素分析を行った。実 験装置からのガスリークを防ぐために，誘導炉直上に水 冷フランジを採用し，密閉構造となるように工夫した。

実験は，石炭炭種，石炭粒径，スラグ温度，石炭熱分 解ガス炬内滞留時間を变えて䘕った。実験に用いた石炭 は, Table 1 に示すように, 11 種類の石炭 (Coal A K ) と 1 種類（L）の治金用コークスで，工業分析值の揮発 分量の順に並べてある. Coal-A，B は亜歴青炭, Coal$\mathrm{C} \sim \mathrm{J}$ は原料炭挹よび-...般炭を含む瀝青炭, Coal-K は無煙炭に属する石炭である。石炭粒径は $0.8 \sim 1.0$, 1.5 3.0, $5.0 \sim 7.0 \mathrm{~mm}$ の 3 種類，スラグ温度は 1350 $\sim 1500^{\circ} \mathrm{C}$, ガス炉内滞留時間は2.5 10.0 s (Ar 流量 を $20 \sim 5 \mathrm{NL} / \mathrm{min}$ と変化させることで実現）の範囲で実 験した。

炉内で発生した熱分解生成ガスを，ガスサンプリング バックに全量捕集するのに必要な Ar 量を決茾するため の予備実験を行った，炉内に発生した熱分解生成ガスを すべて追い出すのに必要な Ar 量は，20 NL 以上である ことがわかり，本実験では，ガスサンプリング量として

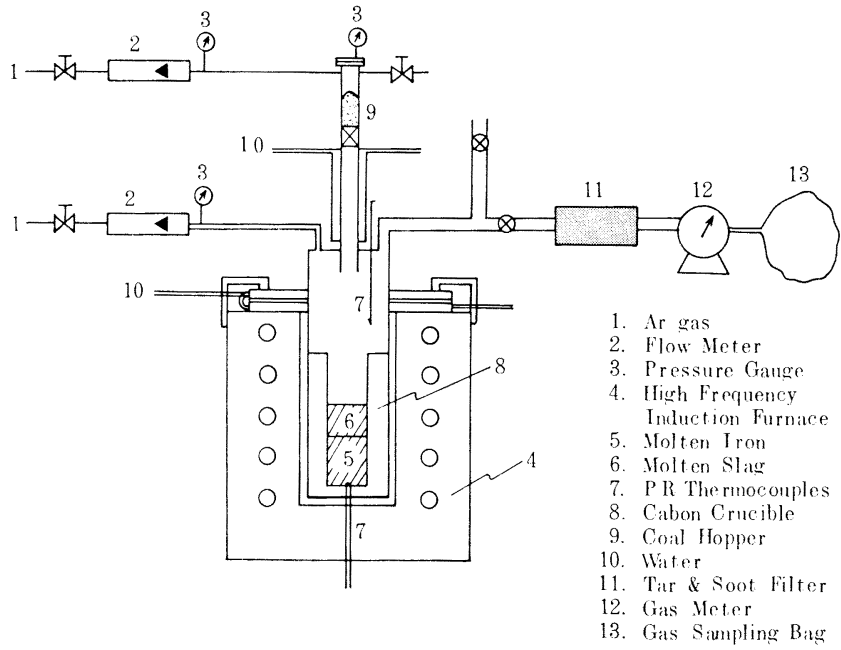

Fig. 1. Experimental apparatus.

Table 1. Proximate and ultimate analysis of coals.

\begin{tabular}{|c|c|c|c|c|c|c|c|c|c|c|}
\hline \multirow{2}{*}{ Coal } & \multicolumn{4}{|c|}{ Proximate (wt $\%)$} & \multicolumn{6}{|c|}{ Ultimate (wt $\%)$} \\
\hline & VM & $\mathrm{FC}$ & Ash & Ms & $\mathrm{C}$ & $\mathrm{H}$ & o & $\mathrm{N}$ & $\mathrm{S}$ & TS \\
\hline A (Japan) & 48.88 & 43.12 & 8.00 & 5.12 & 67.57 & 5.99 & 17.37 & 1.00 & 0.07 & 0.23 \\
\hline $\mathrm{B}$ (Australia) & 45.56 & 44.57 & 9.87 & 8.32 & 69.91 & 5.25 & 14.10 & 0.76 & 0.11 & 0.29 \\
\hline C(Japan) & 38.19 & 53.58 & 8.23 & 1.42 & 74.93 & 4.50 & 10.11 & 1.40 & 0.83 & 0.96 \\
\hline D (South Africa) & 33.23 & 56.56 & 10.21 & 2.47 & 73.83 & 4.68 & 8.99 & 1.78 & 0.51 & 0.64 \\
\hline $\mathrm{E}$ (South Africa) & 32.14 & 59.98 & 7.88 & 2.01 & 76.65 & 4.96 & 8.02 & 1.90 & 0.59 & 0.69 \\
\hline $\mathrm{F}$ (Australia) & 25.11 & 66.20 & 8.69 & 1.44 & 79.51 & 4.57 & 4.99 & 1.76 & 0.48 & 0.54 \\
\hline G(Australia) & 22.15 & 70.81 & 7.04 & 0.90 & 82.04 & 4.60 & 3.98 & 1.86 & 0.48 & 0.51 \\
\hline $\mathrm{H}$ (Canada) & 22.00 & 68.55 & 9.45 & 0.84 & 79.84 & 4.50 & 4.70 & 1.21 & 0.30 & 0.35 \\
\hline $\mathrm{I}(\mathrm{USSR})$ & 18.46 & 72.40 & 9.14 & 0.67 & 81.43 & 4.34 & 4.31 & 0.74 & 0.04 & 0.20 \\
\hline$J$ (Australia) & 18.48 & 73.84 & 7.68 & 1.10 & 80.39 & 4.33 & 5.23 & 1.78 & 0.59 & 0.60 \\
\hline $\mathrm{K}$ (China) & 5.92 & 79.54 & 14.54 & 1.14 & 80.54 & 0.72 & 3.91 & 0.26 & 0.03 & 0.16 \\
\hline $\mathrm{L}$ & 0.67 & 87.95 & 11.38 & 0.28 & 86.52 & 0.02 & 0.32 & 1.11 & 0.55 & 0.62 \\
\hline
\end{tabular}


Table 2. Proximate and ultimate analysis of chars pyrolyzed on molten slag (Slag temperature $1400^{\circ} \mathrm{C}$, coal diameter $1.5 \sim 3.0 \mathrm{~mm}$ ).

\begin{tabular}{|c|c|c|c|c|c|c|c|c|c|}
\hline \multirow{2}{*}{ Char } & \multicolumn{3}{|c|}{ Proximate $(w t \%)$} & \multicolumn{6}{|c|}{ Ultimate $(w t \%)$} \\
\hline & VM & $\mathrm{FC}$ & Ash & $\mathrm{C}$ & $\mathrm{H}$ & 0 & $\mathrm{~N}$ & $\mathrm{~s}$ & TS \\
\hline A (Japan) & 1.13 & 83.25 & 15.62 & 82.93 & 0.06 & 0.53 & 0.71 & 0.15 & 0.35 \\
\hline $\mathrm{B}$ (Australia) & 0.71 & 80.40 & 18.89 & 79.79 & 0.06 & 0.68 & 0.42 & 0.16 & 0.21 \\
\hline C (Japan) & 0.59 & 86.84 & 12.57 & 84.73 & 0.05 & 0.96 & 0.99 & 0.70 & 0.77 \\
\hline D) (South Africa) & $\mathrm{NA}$ & $\mathrm{NA}$ & 16.93 & 80.99 & 0.10 & 1.07 & 0.66 & 0.25 & 0.31 \\
\hline E (South Africa) & NA & $\mathrm{NA}$ & 11.80 & 86.43 & 0.09 & 0.60 & 0.77 & 0.31 & 0.41 \\
\hline $\mathrm{F}$ (Australia) & 0.66 & 86.86 & 12.48 & 86.09 & 0.04 & 0.02 & 1.15 & 0.22 & 0.41 \\
\hline G(Australia) & $\mathrm{NA}$ & $\mathrm{NA}$ & 12.71 & 85.48 & 0.08 & 0.56 & 0.87 & 0.30 & 0.33 \\
\hline $\mathrm{H}$ (Canada) & 0.50 & 87.81 & 11.69 & 86.68 & 0.05 & 0.42 & 0.91 & 0.25 & 0.28 \\
\hline I (USSR) & 0.41 & 87.97 & 11.62 & 86.78 & 0.04 & 0.63 & 0.80 & 0.13 & 0.19 \\
\hline J (Australia) & 0.41 & 88.75 & 10.84 & 87.25 & 0.05 & 0.04 & 1.35 & 0.47 & 0.49 \\
\hline $\mathrm{K}$ (China) & 1.00 & 84.94 & 14.06 & 84.82 & 0.12 & 0.59 & 0.35 & 0.06 & 0.14 \\
\hline L & 0.44 & 87.42 & 12.14 & 85.48 & 0.05 & 0.81 & 1.03 & 0.49 & 0.55 \\
\hline
\end{tabular}

NA : Not Analyzed

$20 \mathrm{NL}$ 以上を目途にガス捕集を行った。 EsSFNHIGH ${ }^{10)} や$ AGARWAL $^{11)}$ の検討によれば，本实験に使用した石炭粒径 の範讲で，熱分解に要する時間は $1000^{\circ} \mathrm{C}$ 以下の低温 でも $60 \mathrm{~s}$ 以内であり，60 240 s の捕集時間を確保して いる本実験では，十分に熱分解が終了していると考えら れる.

Table 2 には, 生成したチャーの、業分析および元素 分析の結果を示す.

\section{3. 実験結果と考察}

\section{$3 \cdot 1$ 全揮発分発生量}

熱分解生成物の生成割令の内訳を全岑種について,

Fig. 2 に示す。各成分の生成割命は, 湿分および成分 老除外した重量％（daf-wt％，Dry ash free）で計算 している.チャーの生成割令は, スラグ浴上の回収チャ一 の重量から，ガスはガスクロによる分析結果から求めた ものである。タール+すす+ $\mathrm{H}_{2} \mathrm{O}$ の生成割会は，100\% からチャーおよボガス収率を引いた差として得たもので ある.タールフィルターに捕集されたタール十すすの重 量測定から得られた回收率は, 計算で得られるタール十 すす量の 50 〜 60\% で，残りは配管への付着およびト ラップされずにガスサンプリングバックに散逸したもの と思われる.夕ールとす寸の区別は困難であったが，か なりの量はすす状をしていた。これは，不荻から放出さ れた捙発分がスラグ浴上部の高温空閴でクラッキング $\left(\mathrm{C}_{n} \mathrm{H}_{m} \rightarrow \mathrm{C}+\right.$ 軽質炭化水素) やポリマー化 $\left(\mathrm{C}_{n} \mathrm{H}_{m} \rightarrow\right.$ $\left.-\left(\mathrm{C}_{n} \mathrm{H}_{m}\right)_{k} \rightarrow \mathrm{C}\right)$ の一次次心よって生成したものである.

Fig. 2 から, 丁業分析値の挿発分の多い不炭ほど, 残 留チャー量が少なくなる傾问にあることがわかる。

この実験による全捕発分発生量 $\left(V^{*}\right.$ ，ガス扰よび夕一 ルすす $+\mathrm{H}_{2} \mathrm{O}$ 収率の和) と業分析値の揮発分 $(V M)$ の比較を示したものが，Fig. 3 である。 $V^{*} / V M=1.0$ の線が、下業分析値と间じ揮発分量が得られたことを意

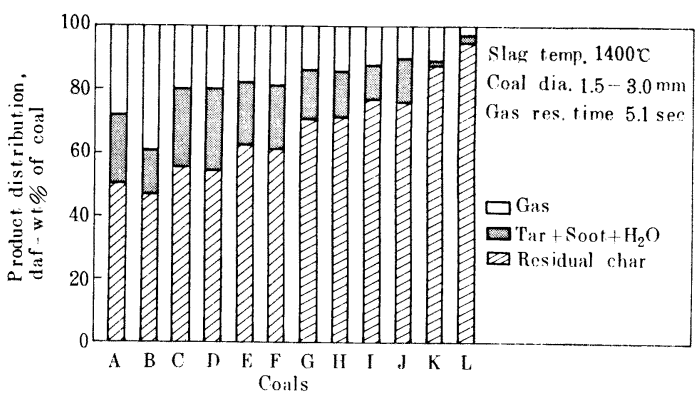

Fig. 2. Product distribution of various coals pyrolyzed on molten slag.

味する，スラグ温度 $1400^{\circ} \mathrm{C}$ (们炭粒径 $1.5 \sim 3.0 \mathrm{~mm}$ ) の高温浴での急速加熱条作下では，全掩発分発牛量 $\left(V^{*}\right)$ は，荻種によって花十の相違があるが，ほとん どの石炭で】業分析值をは:[1]り，10－20\% 増の結果が 得られた。Coal-F 扩よび舆䙳获のCoal-K では，掉発 分の発生㓶合が非常に多くなり，発生星の比は，そ机ぞ れ 1.4 および 1.75 という值になる。本占験の加熱速度 は，不荻粒内の温度么配を無視して推算すると、䄪 $5000 \mathrm{~K} / \mathrm{s}$ 程度となる。ANTHONY ら ${ }^{2)}$ は, 多くの研究者 の急速加熱実験の絬果をまとめ，加熱速度 600－50000 $\mathrm{K} / \mathrm{s}$, 温度 $1000^{\circ} \mathrm{C}$ 近傍の低洫で $V^{*} / V M$ が 0.75 1.36 の範囲にあり，ほとんどのデータが 1.0 を超える と報奖している。加熱速度の影響は，ある…昰速度以上。 では， $V^{*} に$ にえる影響は小さいとしている。また，

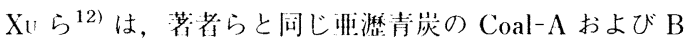
の 200 メッシュ以下のものを用いて, キューリーポイ

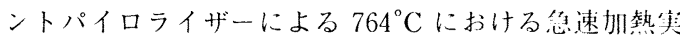
験 $(3000 \mathrm{~K} / \mathrm{s})$ を行い， $V^{*} / V M$ がそ机ぞれ 0.95 拉よ び 1.04 の結果を得ている。著者らの結果は, Coal-A および B の $1.5 \sim 3.0 \mathrm{~mm}$ の粗精で，それぞ扎 0.94 㧍

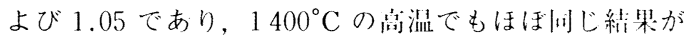




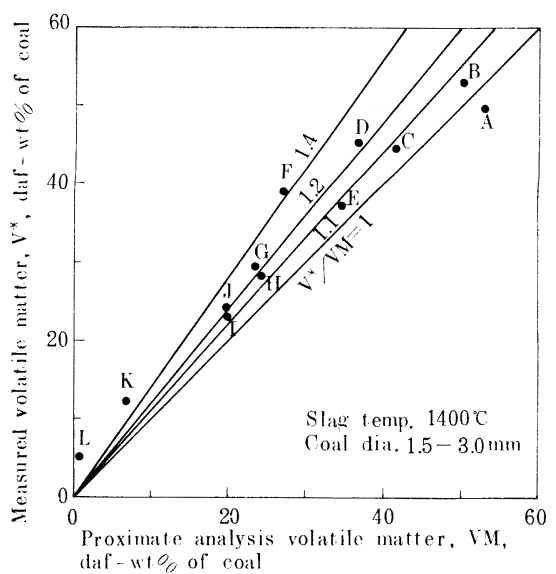

Fig. 3. Comparison of volatile matter produced on molten slag with proximate VM.

得られた。

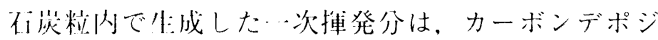

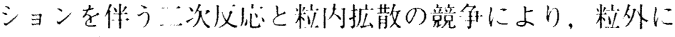

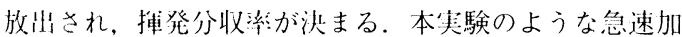
熟では，低速加熱に比べて，一次仪忍の機会が少なくな る(搪散が優位となる)ことから，捕発分量が大きくな るものと思われる21.

Fig. 4 抢よびFig. 5 にスラグ温度抢よび不炭档往の 军揮発分発生量に及ぼす影響を赤す。スラグ温度 1350 ～1500 ${ }^{\circ} \mathrm{C}$ 抢よび们荻䊑往 0.8〜7.0 mm の範讲では, 实験呮算によるデー夕の茯けのばらつきはあるが，全捕 発分量に及ばすスラグ温度打よびイ谈䊉径の影響はあま り光ら机ない。

全摶発分発生量 $\left(V^{*}\right)$ と住荻中 $[\mathrm{C}]_{d a f}$ との関倸を プロットすると Fig. 6 に亦すように強い相関があり， 最小三乗法による近似をすると，以下の(1)式が得られ る。

$V^{*}=-2.148[\mathrm{C}]_{d a f}+217.8$

ここに, $V^{*}$ : 金捙発分発生割会, daf-wt \%, [C $]_{d a f}$ : 石炭中 $\mathrm{C}$ 元荅含有割令， daf-wt％である。適用範䎴は， 温度 $1350 \sim 1500^{\circ} \mathrm{C}$, 石炭粒径 0.8 7 mm である。溶 融還元の条件下では，ほぼ( 1 )式で搏発分発生量の推定 が種々の不炭について叮能となろう。

\section{$3 \cdot 2$ ガス成分分布}

熱分解生成ガスの成分分布をすべての炭種について,

Fig. 7 に示す，不荻の熱分解によって生成する主なガ 又成分は, $\mathrm{H}_{2}, \mathrm{CO}, \mathrm{CO}_{2}$, 抢よび軽質炭化水素 $\mathrm{CH}_{4}$ $\mathrm{C}_{3} \mathrm{H}_{8}$ の各成分である. Fig. 7 の $\mathrm{H}_{2} \mathrm{O}$ は, 計算により 求めたもので, 不炭中 [O] 光素のうち, チャ一中の [O]

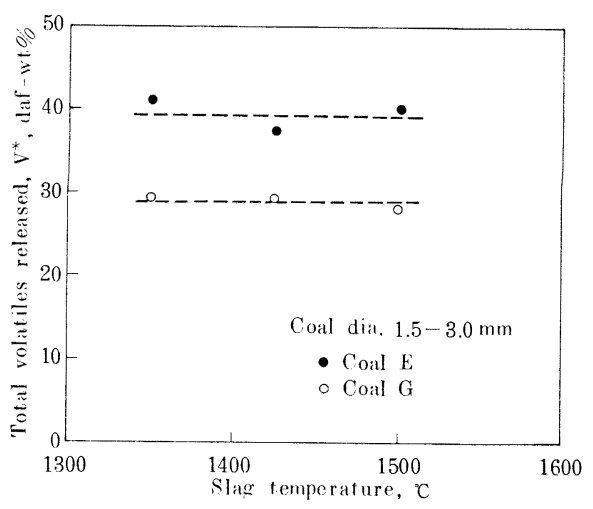

Fig. 4. Effect of slag temperature on volatile matter yield.

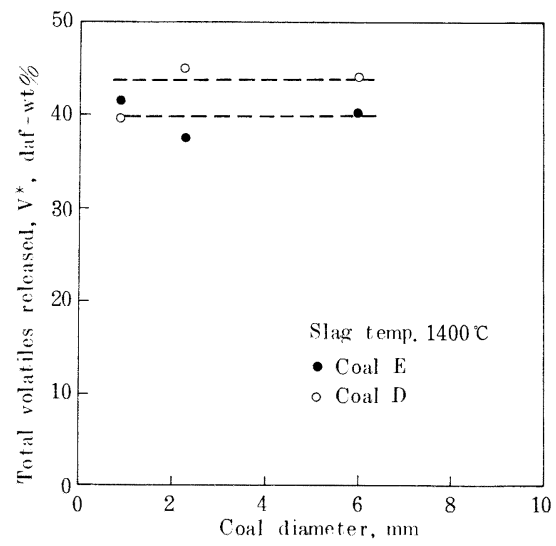

Fig. 5. Effect of coal diameter on volatile matter yield.

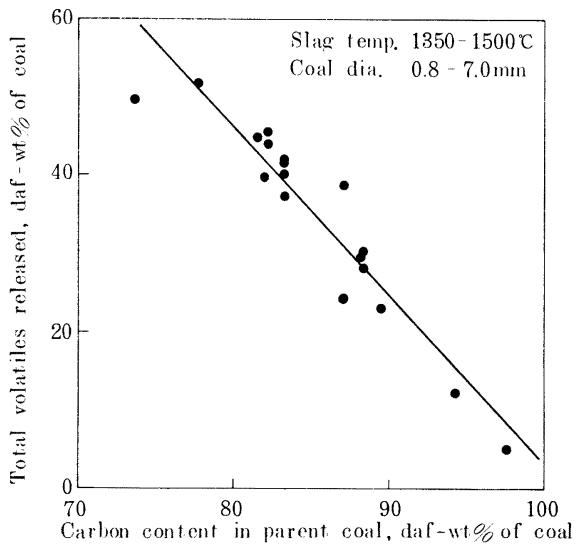

Fig. 6. Total volatiles released in the pyrolysis of coals on molten slag. 


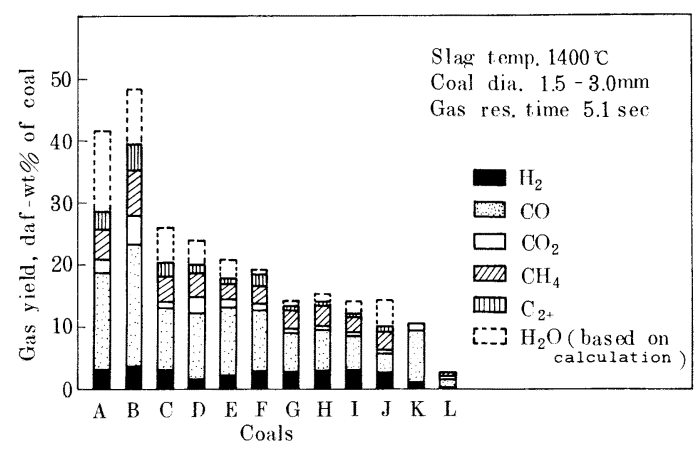

Fig. 7. Distribution of gas components produced from various coals.

元素および $\mathrm{CO}, \mathrm{CO}_{2}$ ガス中の [O] 元素を引いた残り の [O] 元素は, すべて $\mathrm{H}_{2} \mathrm{O}$ に含まれると仮定している. タールおよびすす中の [O] 元素は非常に少ないと考え られ，無視している. Coal-K および L では分析䛊差が 大きく除外した。

熱分解ガス成分のうち, $\mathrm{H}_{2}$ の生成割命は, 石炭重量 の 2.5 - 3.5\% で炭種によって大きな差異はない。軽質 炭化水素 $\left(\mathrm{CH}_{4} \sim \mathrm{C}_{3} \mathrm{H}_{8}\right)$ の生成割会は, 揮発分の多い 不炭ほど多くなる。65８0\% は $\mathrm{CH}_{4}$ が占めており，残 りは $\mathrm{C}_{2} \mathrm{H}_{4}, \mathrm{C}_{3} \mathrm{H}_{6}$ の不飽和岑化水素である. $\mathrm{C}_{2} \mathrm{H}_{6}$, $\mathrm{C}_{3} \mathrm{H}_{8}$ の飽和炭化水素は高温での二次分解のために検出 さ机なかった，軽質炭化水素の生成割合は，石炭中の [H]/[C] の比により，Fig. 8 に示すようにある程度， 推測することができる.

$\mathrm{CO}, \mathrm{CO}_{2}$ の含酸素化合物は, Fig. 9 に示すように, 石炭中 [O] 元素の含有量と密接な関連があり, 石炭中 [O] 元素に比例して, $\mathrm{CO}+\mathrm{CO}_{2}$ の生成量は大きくな る. 石炭中 [O] の多い Coal-A, B では $\mathrm{CO}+\mathrm{CO}_{2}$ 収 率が不崖重量の $20 \%$ にも達する。 $\mathrm{CO}+\mathrm{CO}_{2}$ のうち, COの占める割合は炭種にかかわらず，90\%程度にな る. 不炭中 [O] 元素の含酸素化合物への分配は，低温 では $\mathrm{CO}_{2} \cdot \mathrm{H}_{2} \mathrm{O}$ 、高温になるほど $\mathrm{CO}$ へ移行するこ とが知られている5)13).

熱分解生成ガスにおけるシフト文心 $\left(\mathrm{CO}+\mathrm{H}_{2} \mathrm{O}=\right.$ $\mathrm{CO}_{2}+\mathrm{H}_{2}$ ) の平衡を検討してみる. 実測された $\mathrm{H}_{2}, \mathrm{CO}$, $\mathrm{CO}_{2}$ および計算で求めた $\mathrm{H}_{2} \mathrm{O}$ から実験的に求まるシフ トメ心乎衡定数 $K_{e x p}=\left[\mathrm{CO}_{2}\right]\left[\mathrm{H}_{2}\right] /[\mathrm{CO}]\left[\mathrm{H}_{2} \mathrm{O}\right]$ と理 論的に得られる平衡定数 $K_{t h}$ をいくつかの石炭につい て，Fig. 10 に示す。実験的に求まる平衡定数は，理論 平衡定数の温度 $1000 \sim 1500^{\circ} \mathrm{C}$ の範囲にほぼある。実 験装置のスラグ浴上部空間の温度は $1000 \sim 1400^{\circ} \mathrm{C} に$ あることを考えると, 熱分解生成ガスの $\mathrm{H}_{2}, \mathrm{CO}, \mathrm{CO}_{2}$,

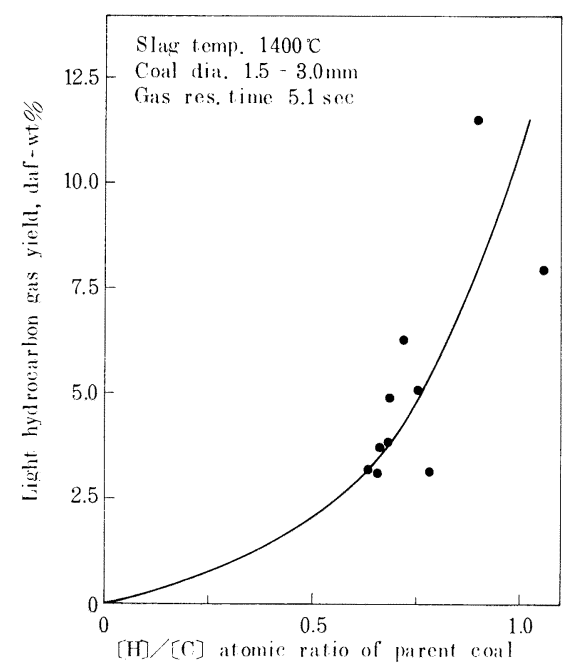

Fig. 8. Relation between light hydrocarbon gas yield and $[\mathrm{H}] /[\mathrm{C}]$ ratio in coal.

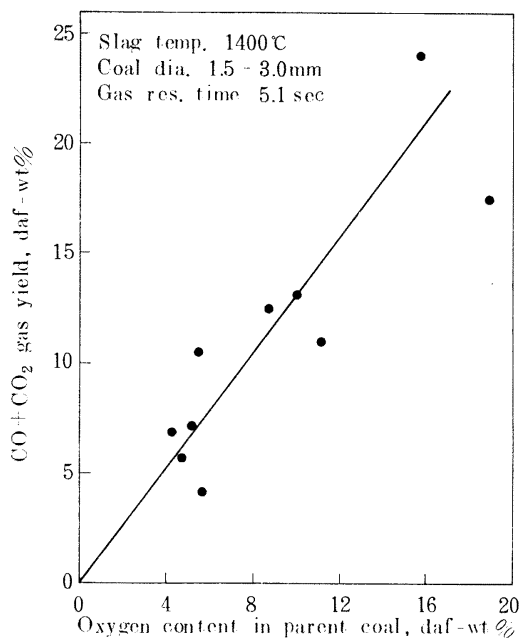

Fig. 9. Relation between $\mathrm{CO}+\mathrm{CO}_{2}$ gas yield and [O] in coal.

$\mathrm{H}_{2} \mathrm{O}$ は，溶融還元相当の高温では，ほぼシフト文心の 平衡組成に近くなると考えられる。

Fig. 11 に熱分解生成ガスの烟内㵽留時間のガス収率 に及ぼす影響を亦す。炍内ガス滞留時䦌が，2.5 s から

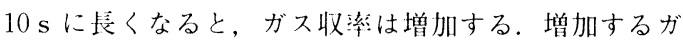
ス成分は, $\mathrm{CO}$ 拈よび $\mathrm{H}_{2}$ であり, 軽質炭化水素ガスは, やや減少する方问にある。これは，为内高温度場での揮 発分の二次文応を示すものである.

熱分解で生成した $\mathrm{H}_{2} \mathrm{O}$ による夕ール, 炭化水素ガス のリフォーミング反応，タール，崖化水素ガスのクラッ 


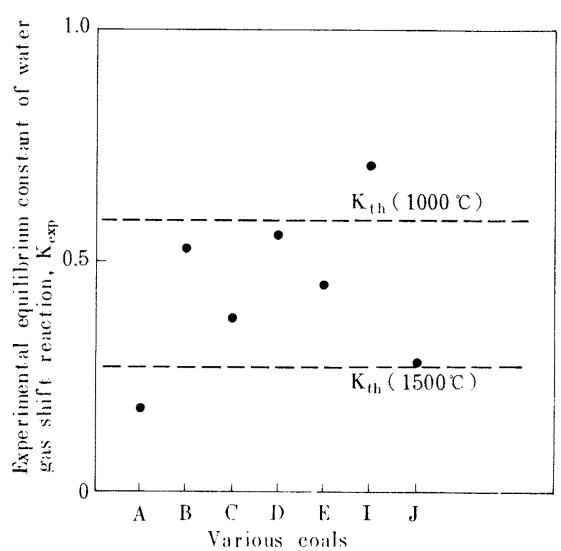

Fig. 10. Comparison between experimental and theoretical equilibrium constants of water gas shift reaction.

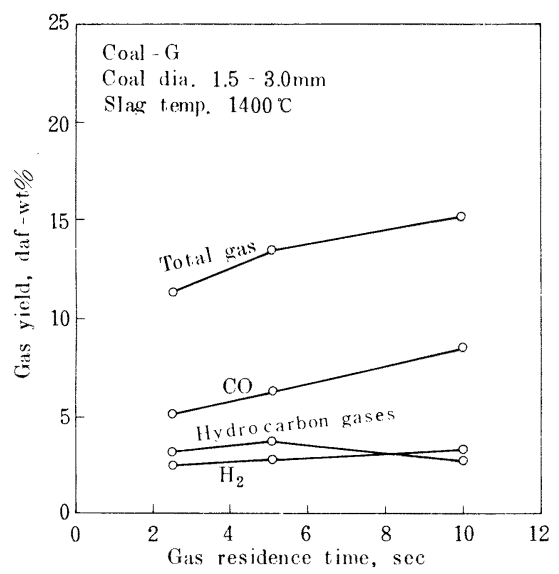

Fig. 11. Effect of gas residence time on gas product yield.

キングおよびポリマー化伩心が滞留時間とともに進行し ている.

\section{$3 \cdot 3$ 石炭中 $[\mathrm{S}]$ および $[\mathrm{N}]$ の熱分解生成物への分配 挙動}

石炭中の [S]や $[\mathrm{N}]$ 元素が，急速熱分解によって， どのように捙発分およびチャー中に分配されるかを知る ことは，溶銑品質を考える上で重要である。

Fig. 12 (a) および 13 (a) に不炭中の Total- [S] (Organic-S + Inorganic-S) と $[\mathrm{N}]$ 元素の残留チャー に保持された割命を $[\mathrm{C}]_{d a f}$ に対して，それぞれ示して いる.

石炭中 [S] のチャーに保持されている割命は，30〜 $70 \mathrm{wt} \%$ で不岑中 C 含有量の少ない低炭化度の石炭ほ どチャー中に残留する [S] の割令が少なくなる，石炭

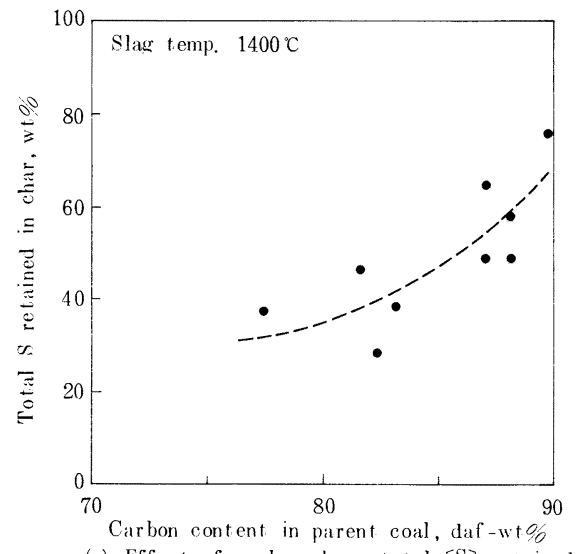

(a) Effect of coal rank on total [S] retained in char

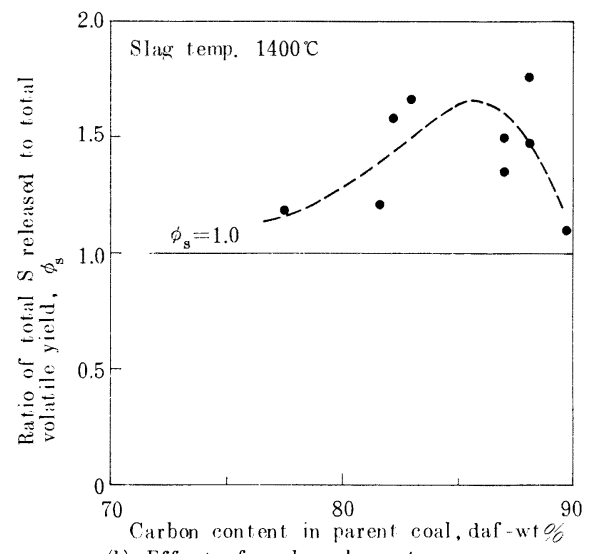

(h) Effect of coal rank on $\phi_{\mathrm{s}}$

Fig. 12. Behavior of total $[\mathrm{S}]$ in various coals under conditions of pyrolysis on molten slag.

中 $[\mathrm{N}]$ も 20〜 $80 \mathrm{wt} \%$ で同様の傾问がある。これは， 低炭化度の石炭ほど揮発分の発生量が多くなることか ら，捕発分として放出さ机る $[\mathrm{S}]$ や $[\mathrm{N}]$ の割命が多 くなるのは，当然の傾问と言えよう.

揮発分としての放出される $[\mathrm{S}]$ および $[\mathrm{N}]$ の放出 されやすさの目妿として， $\mathrm{NEOH}^{6)}$ と同様に以下の規格化 した指標を分義する。

$\Phi_{\mathrm{S}, \mathrm{N}}=($ 揮発分中に放出される $[\mathrm{S}]$ or $[\mathrm{N}]$ の $\mathrm{wt} \%) /$ (全揮発分発生重量割合, wt \% daf-coal) $\cdot(2)$

Fig. 12 (b) および $13(\mathrm{~b}) に[\mathrm{C}]_{\text {daf }}$ に対して， $\Phi_{\mathrm{S}} ， \Phi_{\mathrm{N}}$ の値をそれぞれ示しているが，いずれの石炭も，1.0を 超えている.これは， $[\mathrm{S}],[\mathrm{N}]$ がチャ一中に保持され るより，揮発分として放出されやすい傾问を持つことを 表している，また，不炭のランクによりその值は差異が あり, $[\mathrm{C}]_{d a f}$ が $85 \%$ 程度の石炭に拈いて，ピークを示 


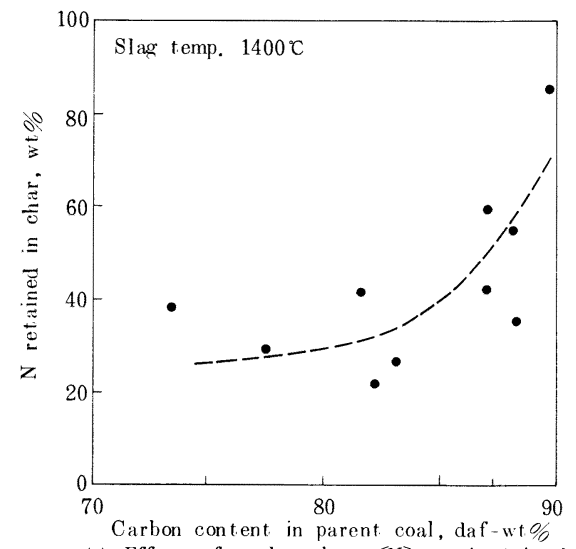

(a) Effect of coal rank on $\mathrm{N}]$ retained in char

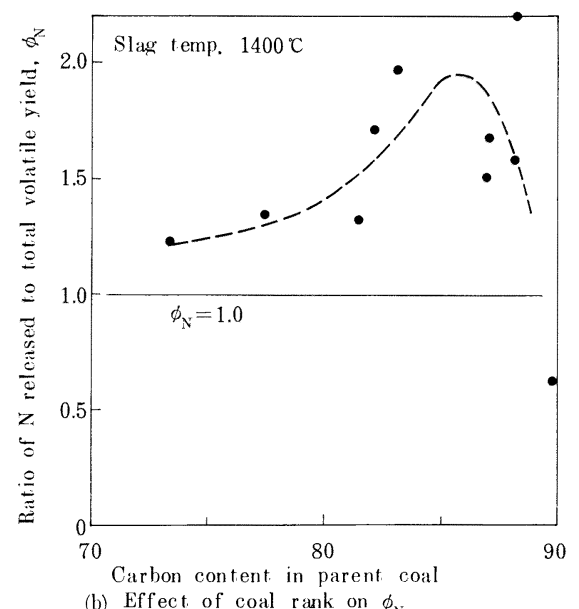

Fig. 13. Behavior of $[\mathrm{N}]$ in various coals under conditions of pyrolysis on molten slag.

すようになる、NEOH らの実験では， $\Phi_{\mathrm{S}}, \Phi_{\mathrm{N}}$ の值は $2400 \mathrm{~K}$ においても，1.0を超えず，本実験結果とかな り相違するが,この相違は，NEOH らの実験が高温下で の石炭の滞留時間が非常に短い（ｍs のオーダー）実 験であるということに起因していると思われる。P Р ら ${ }^{14)}$ は, 低速加熱, 滞留時間の長い実験条件下におい て,チャーの生成量があまり変化しないのに対して, 高温ほどチャー中 $[\mathrm{N}]$ の含有量が減少し, $2000^{\circ} \mathrm{C} て ゙$ はほぼゼロになるという結果を示している，著者らの チャ一中 [N] の残留傾向に近い結果を得ている.

チャー中の [S], [N] の放出は, チャーの高沮場で の滞留時間の影響を受け，溶融還元反心条件下では，捕 発分への放出が多くなり,チャー中の残留は少なくなる.

\section{4. 結言}

溶融スラグ浴上で，種々の石炭の急速熱分解仪灾実験
を行い，文忘生成物を定量的に把握することで，以下の 点が明らかになった。

(1) 溶融スラグ浴上における不菼熱分解時の捕発分発 生量は，工業分析值の揮発分に比べて，10～20\% 増と なる，溶融還元条件下では，搏発分発生量は以下の式で 推測できる.

$$
V^{*}=-2.148[\mathrm{C}]_{d a f}+217.8
$$

(2)石炭揮発分発生量の不岑粒径・スラグ温度の影響 は, 粒径 $0.8 \sim 7.0 \mathrm{~mm}$, 温度 $1350 \sim 1500^{\circ} \mathrm{C}$ の実験範 井では大きくない。

( 3 )石炭揮発分中のガス成分は, 主に $\mathrm{CO}, \mathrm{CO}_{2}, \mathrm{H}_{2}$, $\mathrm{CH}_{4} \sim \mathrm{C}_{3} \mathrm{H}_{6}$ であるが, このうち, 軽質炭化水素ガスの $\mathrm{CH}_{4} \sim \mathrm{C}_{3} \mathrm{H}_{6}$ 発生量は, 不荻中 $[\mathrm{H}] /[\mathrm{C}]$ の比により子 測できる。また，含酸素化令物の $\mathrm{CO}, \mathrm{CO}_{2}$ の発生量は, 石炭中 [O] 元素含有量が大きいほど大きくなる.これ らのガスは, 水性ガスシフト皮忠の壮衡組成に近くなる.

(4)炉内ガス滞留時閏が言くなると，ガス発生量が多 くなり， $\mathrm{H}_{2}$ および $\mathrm{CO}$ 成分が増加する傾问になる。

( 5 )石炭中 $[\mathrm{S}],[\mathrm{N}]$ のうち，生成チャーに残留す る $[\mathrm{S}],[\mathrm{N}]$ の割会は, ランクの高い不岑ほど多くなる. 揮発分への放出されやすさの指標である $\Phi_{\mathrm{S}, \mathrm{N}}$ は，いず れの石炭も 1.0 を超え， [C $]_{d a f}=85 \%$ 近傍の石炭で ピークとなる.

\section{文献}

1) 松尾无高, 斎藤 力, 版裕之, 平浩, 小川雄问: 鉄と鋼，76(1990), p. 1879

2) D. B. ANThony and J. B. Howari): AIChE J., 22 (1976), p. 625

$3)$ G. R. Gaval.As: Coal Pyrolysis (1982) [Elsevier]

4) C. Y. Wen and S. DutTa: Coal Conversion Technology, ed. by C. Y. WEN and S. LEE (1979), p. 57 [Addison-Wesley]

5 ) D. I. Cliff, $K . R$. Dool.an, J. C. Mackik and $R$. J. TYler: Fuel, 63 (1984), p. 394

6) K. G. NFoH and R. E. GANNon: Fuel, 63 (1984), p. 1347

7 ) S. S. Tamhankar, J. T. Sears and $C$. Y. Wen: Fuel, 63 (1984), p. 1230

8 ) W. R. Seeker, G. S. Samuel son, M. P. Heap and J. D. TROLINGER: Eighteenth Symposium (International)on Combustion (1981), p. 1213 [The Combustion Institute]

9 ) N. C. Breck and A. N. Haymurst : Combustion \& Flame, 79 (1990), p. 47

10) R. H. EssenhiciH: J. Eng. Power, 85 (1963), p. 183

11) P. K. Agarwal: Fuel, 65 (1986), p. 803

12) W. C. Xu and A. Tomita: Fuel, 66 (1987), p. 627

13) W. C. Xu and A. Tomita: Fuel, 66 (1987), p. 632

14) J. H. PoHL and A. F. Sarofim: Sixteenth Symposium (International)on Combustion (1977), p. 491 [The Combustion Institute] 